\title{
Role of Pakistani Print Media in Promoting Clean and Green Pakistan Campaign
}

\author{
Moneeba Iftikhar*, Urwah Iftikhar**, Mehwish Mukhtar***
}

\begin{abstract}
The aim of the research is to inspect the role of Pakistani Print Media (Daily Jang, Nawa-i-Waqt, Dawn and The News) in promoting Clean and Green Pakistan Campaign during selected time period from February to April in 2019. A sample of Total 356 newspapers was used in which 112 newspapers were taken from the month of February, 124 newspapers from the month of March and 120 newspapers from the month of April. The research was based on the Issue Attention Cycle by 'Anthony Downs'. In this analysis, in the perspective of news and advertisements published in the selected newspapers, Chi-Square test was applied for two hypothesis testing, the test showed insignificant results for $\mathrm{Hl}$ and significant results for H2.
\end{abstract}

Keywords: Print Media, Clean and Green Pakistan Campaign, Image Building

This Article can be cited as:

Itikhar M., Iftikhar U., Mukhtar M., (2020). Role of Pakistani Print Media in Promoting Clean and Green Pakistan Campaign, Journal of Arts and Social Sciences. VII (2), 24-34.

\footnotetext{
* Correspondence concerning this article should be addressed to Ms. Moneeba Iftikhar, PhD Scholar at CMCS, University of Gujrat, Pakistan, mobi_80@yahoo.com.

**Urwah Iftikhar and Lecturer, Department of Mass Communication, Lahore College for Women University, Lahore, Pakistan, Urwah.iftikhar@1cwu.edu.pk.

****Mehwish Mukhtar is student of BS Mass Communication, Lahore, Pakistan.
} 


\section{Introduction}

Media is a supportive procedure in which depictions are established and processes are carried out, at times by the beginner and sometimes by the source (Kozma, 1991). Print media is one of the most unique way of communicating the problems to the youth in an establish way and in the form of information so the youth can understand it better and have better knowledge and understanding about the world. Print media is among the "necessary" tools of society that helps every individual to communicate and correspond to each other.

Advertising literature has constantly requested the development on evolving areas like globalization in the applications of the advertising in as pacific tradition. The fact of globalization recommend promoting the regional tradition in the advertising certainly problems related to the gender. (Raza, Awan \& Iftikhar, 2018)

Everyone is exposed to the environment constantly and being in a healthy environment is as important as polluted environment can harm all the living beings. Environment problems which we are facing today are alarming to us. Some of the major environmental problems include polluted water which results in polluting the ocean and killing the living things in it and shortage of clean and drinkable water, air pollution which is causing severe climate changes which results in very hot or cold weather in different parts of the world (Maibach, 2010).

Necessity of metals for some raised plants and animals is now well documented; thus, its raised collection is fatal for plants, animals and human beings. Growing instruction of the burning of crop remnants and handing out by-products has motivated interest in the use of composted cultivation method byproducts as soil revisions and agricultural growing media (Mathews \& Thurkins, 2006).

The idea of essential water, which is the capacity of water utilization needed to create products exchanged to an importing or exporting country (or any area, organization, individual, etc.), is a useful addition to water method analyses of water accessibility and use by locality. Recognizing the source of essential water, such as precipitation (green water) and irrigation water (blue water), further increases this idea because each varies in the level of assistance and opportunity cost. (Hanasaki, Inuzuka, Kanae \& Oki, 2010)

The concept that growing countries should share the responsibility for weather change is an example of environmental colonialism. The method in which the global warming argument is being carried out is only improving and growing the North-South divide. A main issue is how to divide the global commons of carbon dioxide and methane sinks. A system of global exchangeable permits should be established to control global greenhouse gas discharges. (Agarwal \& Nairan, 1991)

People often throw garbage and dust on the roads and footpaths instead of trashing it in rubbish containers. This is how slowly the garbage increases and changes into immense litter. If this litter is not scrubbed, further it smells bad and cause the diseases which affect the people. Therefore, there would be many consequences or troubles which society and people will face that live in that environment, if we do not keep our environment clean (Sethi, 2016).

It is important to keep our environment clean to live healthy, well, disease free and pollution free. There are almost 7 billion people living in our world and frequently we are producing an immense amount of waste from our daily life. If the waste does not manage on a regular basis then the amount of waste will increase gradually and we will be unable to live just because of polluted environment (Adelaide, 2018).

The Greenpeace Report, written by main scientists and energy investigators all over the world, describes the scientific information and assesses its suggestions. Commissioned as an outline report to the results of the Intergovernmental Panel on Climate Change (IPCC), the document shows the vital 
calculations that the strategists ought to be asking our officials to adopt if we are to get away what could be the most important ultimatum our planet has ever faced. (Leggett, 1990)

The federal government of Pakistan introduced the Clean Green Pakistan Program. This is a first good initiative because it is everyone's duty, and emphasizes on behavioral change to form need for better climatic conditions. With this step, the government is creating awareness about the value of natural resources in urban areas and significance of preserving them. Pakistan can reinforce its environmental protection departments' ability to reveal climate information and attract people in environmental control by recognition campaigns on contamination and green development, as part of the Clean Green Pakistan initiative (Dawn, 2019).

\section{Need of the Study}

Pakistan is among the twelve countries suffering badly from pollution. Air pollution in Lahore is $77.21 \%$ that is very high, dirty and untidy condition are $58.39 \%$ that are moderate, dissatisfaction with green and parks in the city $37.78 \%$ which is very low. According to purity and quality of cleanliness Air quality is $22.79 \%$ which is very low, garbage disposal dissatisfaction is $40.62 \%$ in Lahore (Kamran, 2017). Globally Pakistan is at the $12^{\text {th }}$ number and in Asia Pakistan stands at the first number in deforestation. Environmental conditions in Pakistan such as deforestation, air pollution and land pollution, are serious environmental problems that Pakistan is facing. Clean and Green Campaign was started by government of Pakistan in October 2018 to aware youth about this campaign through different platforms (Web desk, 2018).

This study entails to explore the part of newspapers in providing information to people which can help to resolve the environmental issues. Print media refers to the top leading newspapers in this study. Data of Nawa-i-Waqt, Jang, Dawn and The News, newspapers of Pakistan and analyze their role in educating the public about major issues related to environment and the way how these issues are highlighted in the news and advertisements. The research will evaluate the role of newspapers in highlighting the environmental issues effectively to the people in the form of news and advertisements.

\section{Objectives of the Study}

- To find out the coverage of news and advertisements related to 'Clean and Green Pakistan' Campaign published in Urdu and English leading Pakistani newspapers.

- To analyze the content published in Nawa-i-Waqt, Jang, Dawn, and The News in the perspective of 'Clean and Green Pakistan' awareness creation among youth.

\section{Hypothesis}

H1: Pakistani newspapers are giving enough coverage to 'Clean and Green Pakistan' campaign.

H2: Urdu print media/newspapers give more coverage to 'Clean and Green Campaign' than English Print Media/newspapers.

\section{Literature Review}

Rahim \& Zukni (2012) research regulates to discover the intensity of consciousness and viewpoint on green living amidst Malaysian youngsters by using advertising. The core purpose is to investigate understanding and viewpoint of Malaysian youngsters about green advertising advanced by the government. A study was organized to collect answers from internet participants using the social website. 3,020 participants have reacted to the six month study time, to a 20 questions questionnaire. The outcome shows that, normally, the Malaysian youngsters have some understanding on what the phrase 'green living' means. Therefore, those who execute green living are less. They have been revealed to green advertising, but everyone do not execute green living because of less comprehensive knowledge of the idea. The Malaysian youngsters show positive viewpoint towards green advertising. The result infers that present and 
future green advertising is needed, importantly ones that are done by the authority to refine on their message transferring, innovation and knowledge Fauziah Ahmad \& Novel Lyndonmation for the youth to react in use.

Stafford \& Chowdhury (2012) described that green advertising practices have become rapidly admired as more environment friendly goods are launched. Subsequently, recognizing which green appeals are the most influential become a critical issue. This research used two samples to study the capable advantages of seven defined green issues as advertising appeals. Findings recommend that health-based green appeals might be the most influential advertising message techniques for the young college-educated students. Findings also show that although adults might prefer health, waste, and energy issues, the older people may not be as delicate to definite green issues. Moreover, the results show that college women may be more involved than college men to waste and wildlife appeals.

Todd \& Peloza (2014) explained that there are two types of advertising appeals for environmentally benefitted commodities and strategies: those that give consumer advantage (e.g., cost savings) and those that give social advantage (e.g., lower emissions). This study investigates the function of decision-making and utilization backgrounds on the effectiveness of each appeal.

Stamm, Clark \& Eblacas (2000) explained people interpretation of global warming, also known as global climate change, is used here as an example of a mass communication issue that has yet to be properly solved. A study of metropolitan region locals found that although public has understanding of this issue in a common way, understanding of certain problems, possible results, and solutions is more restricted. Both mass media and interpersonal communication seem to make a positive part to interpretation, as well as to preserving some common misunderstandings.

Akram et al., (2018) Climate change is one of the biggest concerns because its potential impact on human life is severe. The contribution ratio of $\mathrm{CH} 4, \mathrm{CO} 2$, and $\mathrm{N} 2 \mathrm{O}$ to global warming would be high even if their emission rates are small. Paddy areas may become contaminated by the aggregation of several pollutants, i.e., organic and inorganic fertilizers; discharges from the rapidly increasing industrial regions; use of manure, and organic solid waste; and wastewater irrigation system.

Walsh, Molyneux \& Birley (2011) directs amends in the ecology of vectors and epidemiology of vector-borne diseases which are caused by deforestation. Chosen examples are observed from viral and parasitic contaminations (arboviruses, malaria, Chagas Disease and schistosomiasis) where disease samples have been rightly or incidentally impacted by deprivation of natural tropical forests. A broad variety of projects have turned in deforestation. Colonization and community, trans-migrant programs, logging, agricultural projects to supply for cash crops, mining, hydro-power evolution and fuelwood assembly are included. Each project affects the regularity, frequency and distraction of vector-borne disease. Three core areas are examined - South America, West \& Central Africa and South-East Asia.

Vitousek, (1983) explained rapid waste of carbon, nitrogen, phosphorus, and sulphur are caused by deforestation from worldly ecosystems. More than half of the $\mathrm{C}$ and $\mathrm{N}$ and a bit less $\mathrm{P}$ and $\mathrm{S}$ can be wasted in sites where forest ground is changed to other uses.

Witte and \& (2000) studied fear appeal in a thorough combination using meta-examination methods. The meta-examination recommends that powerful fear appeals create high levels of discerned seriousness and sensitivity, and are more effective than low or weak fear appeals.

Ferraz, Nichols, Hines, Stouffer, Bierregaard \& Lovejo (2007) contrasted large adjacent areas with small detached habitat marks scarce various types. Some species vanish after separation; others are hardly found in any small mark, despite of separation. We used a 13-year information group of bird imprisons from a huge landscape-operation inquiry in a Brazilian Amazon forest to imitate the destroyed-colonization 
potent of 55 species and experimented primary guesses of island biogeography and met population concept. From our models, we extracted two marks of species unprotected to changes in separation and mark area. We discovered a solid impact of area and a changeable impact of separation on the forecasted mark inhabited by birds.

Forchhammer \& Kozlov (2000) said that growing greenhouse gas masses are supposed to have important effects on the global environment on a timescale of decades to centuries. Verification from longterm observing studies is now assembling and recommends that the environment of the past few decades is irregular contrasted with past environment changes, and that recent atmospheric trends are already impacting species physiology, distribution and phonology.

Faisal, Qamer, Murthy, Abbas \& Bhatta in (2014) describes that deforestation is a main climatic question in the hilly areas of Pakistan. The investigation evaluated modes in the forest cover in Chitral tehsil over the last two decades using administered area cover division of Landsat TM satellite images from 1992, 2000 , and 2009, with a maximum probability algorithm. In 2009, the forest cover was $10.3 \%$ of the land area of Chitral (60,000 ha). The deforestation rate raised from $0.14 \%$ per annum in $1992-2000$ to $0.54 \%$ per annum in 2000-2009, with 3,759 ha forest lost over the 17 years. The spatial drivers of deforestation were explored using a cellular automaton modelling skill to estimate future forest conditions.

Qamer, Abbas, Saleem, Shehzad, Ali \& Gilani (2012) examined the special and secular forest cover variations in Swat and Shangla districts to interpret the deforestation method in background of the current safety dispute in these areas. We used multi-purpose satellite images to evaluate the long time deforestation from 2001 to 2009 and also to recognize periodic forest cutting lands deforestation recognized through the dispute time while 1268 ha of gross yearly deforestation were evaluated within last eight years. Majority of the deforestation marks continue throughout the managerial margins at sub-district levels (tehsils) which can be assigned to obscurity in uncertain authority between the forest official. The findings point that the forest cutting emerged in Swat and Shangla through the dispute time is not as important when contrasted with the long term deforestation design in the land. At one side the findings of the research are helpful to the image that appears from worldwide researches which describe high figure of deforestation in the country while on the other hand it contradicts any link connecting the security condition and the growing deforestation in the north western Pakistan. The research dissolves that deforestation evaluations need confirmation by independent sources of information, like satellite imagery to refine our perception of deforestation methods.

Asif Saeed (2002) organized a workshop in December 2002 to recognize the fundamental reasons of deforestation and forest decay in Pakistan. It gives a small review of the various stake holder's viewpoint on forests and forests decay in the country. The aim of this research is to focus problems of deforestation and methodically recognize its fundamental reasons, by including the perceptions of all contributors, forestry zone authorities and strategists from the federal, provincial and regional levels. The basic reasons of deforestation are preparing population demand, reliance of urban and rural clans on fuelwood, interruption of forest authorities in natural forests, unscientific cropping over carrying range, floods, fires and storms, insufficient economic inputs, and contributors' scarcity of participation in the strategy making method. The ventures of the timber Mafia and lack of political interest on the part of the authority to bring them to book have additional provoked the situation. The investigation recommends, that engagement of all the contributors in the strategy making activity, irrelevant of their interests, should go a long way to seize the sharp forest turn down in the country.

Parrish \&Tong Zhu (2009) described that many big cities (with populations more than 10 million) increased from 3 in 1975 to 19 in 2007, and is expected to raise to 27 in 2025 . These big cities are the causes of increasing finances, but are also very huge sources of air contaminants and environment-forcing agents. The increase of big cities greatly irritates the health effects of contaminated air, yet it may also give a chance 
to reduce environment change, if applied air quality strategies are developed to also decrease global warming.

Ali, Benjaminsen, Hammad \& Dick (2005) said that deforestation in the Himalayas is usually perceived as caused essentially by increase in population. Depending on interviews and the study of satellite images, we interpretatively analyze this viewpoint using Basho Valley in the Western Himalayas of Pakistan as a case study. Our results show that the forest of Basho has been decreased by at least $50 \%$ after the valley was opened up by building of a link road in 1968. Large-scale legal and illegal business harvesting was carried out after building of the road. While legal business harvesting was stopped in 1987, illegal harvesting has since continued with the complication of the Forest Department. The results of this research do not help theories in which deforestation is ascribed to high population increase. Whereas, misadministration and illegal business harvesting inscribed by the Forest Department have been the major reasons of deforestation in Basho Valley.

Due to scientific and public interest about health and the environment, "Green", "Eco", "Environment-friendly" operations have been initiated into various research areas. In examination of pharmaceuticals and cosmetics, inspection strategies are used for routine inspection, balanced studies and quality domination, but they can significantly impact researchers' health and protection and have a damaging effect on environment. As a result, researchers' observation is diverted towards greening inquiry process and developing taking into account the ideas of green analytical chemistry (GAC) within their inquiry process. (Mohamed, 2015)

\section{Conceptual Framework}

The conceptual framework is the most important aspect in the process of study. It permits the criticism research to be strong and formed in an orderly flow from one chapter to the next (Randy, 1996). The study is concerned with the evaluation of Newspapers of Pakistan (Nawa-i-Waqt, Daily Jang, Dawn and The News) in the context of promoting Clean and Green Pakistan Campaign, news and advertisements being published in these newspapers.

Downs presented the idea of the issue-attention cycle formed on his viewpoint of the ecology issue rather than on a quantitative analysis of issue salience. This article uses changes in U.S. federal government organizations as a signal of strategy task. Organizational investment may be followed by a lack of any organizational task, but it is more classically accompanied by time spans of organizational progression (that is, substitute of the original initiations). The time spans of topmost organizational strategy in a certain plan area are normally, but not universally, their time spans of topmost relative strategy salience contrasted to total government organizational strategy. Modification in organizational strategy are linked to variations in the major of issues in public opinion. Peak times of organizational strategy happen either during the time of peak public interest with an issue or in the time immediately after that peak in public interest (Peters \& Hogwood, 1985).

The 'Issue Attention Cycle' is a theory of the timespan that Americans introduced and then moved on with an issue. Described as the natural dynamic of the Issue Attention Cycle, in which some issues follow a projectable five stage process. More than 30 years ago, Anthony Downs wrote about a cycle that impacts many domestic public policy issues.

In the present study, Issue Attention Cycle Model is related to the research topic "Role of Print Media in Promoting Clean and Green Pakistan Campaign". Issues related to different sectors are being highlighted frequently in the media. Media being the tool of communication has a great influence on the way people think and perceive their surroundings. Issue attention cycle model is essential in determining the process of environmental issues being stressed in the print media. 
All the issues attract the attention of public for a short period of time. Pakistan is currently facing several environmental issues and print media is emphasizing on the importance through its content and creating awareness among the public. According to Down's theory of Issue Attention Cycle, the issues go through five stages, from recognition and attention to losing its attention among the public b6ut it has been decided that first three stages will be studied under the research topic "Role of Print Media in Promoting Clean and Green Pakistan Campaign" because these three stages are related and relevant to the research topic.

The first stage includes media, specialists and interest classes start elevating an issue or crisis. Pakistan is among the top twelve countries due to pollution while in Asia Pakistan at the first number in pollution.

A lot of times print media highlighted this issue that this is because of deforestation. Likewise, the ratio of deforestation in Pakistan in the previous decade of the last century was higher than other countries in the same income class, regardless of better financial growth (UNEP, 2013). According to Anthony Down's, in Second stage the side effects of the issue are highlighted such as in Pakistan the erosion of trees can create climate change, desertification, soil deprivation, lesser crops, increasing flood, high greenhouse gases in the environment, and a host of issues for local people. "Seventy percent of Earth's land animals and plants live in forests, and many cannot survive the deforestation that destroys their homes."

The third stage of Down's Model includes the solution of the problem as the Federal Government of Pakistan launches Clean and Green Pakistan Campaign to resolve the issue of deforestation in Pakistan. By applying the Issue Attention Cycle Model on the research topic, the researcher will be able to observe the trends of Clean and Green Pakistan Campaign coverage in print media for people and the manner in which this campaign is communicated to its public.

\section{Research Methodology}

Qualitative research method of content analysis was adopted for the study. "Purposive Sampling" is used to conduct this study. The sample is comprised of all selected 4 newspapers published and circulated during three months which includes two Urdu newspapers and two English newspapers and on daily basis all newspapers were analyzed. That collectively make 356 newspapers, 112 newspapers from the month of February, 124 newspapers from the month of March and 120 newspapers from the month of April. The unit of analysis is news and advertisements related to the issue.

\section{Hypothesis Testing \& Discussion}

The first hypothesis states, "Pakistani newspapers are giving enough coverage to 'Clean and Green Pakistan' campaign." The Pearson Chi-Square test was applied to check the content validity shown in the Table I.

Table 1

\begin{tabular}{llll}
\hline \hline & Value & df & Asymp. Sig. (2-sided) \\
\hline Pearson Chi-Square & $.049^{\mathrm{a}}$ & 6 & 1.000 \\
Likelihood Ratio & .049 & 6 & 1.000 \\
Linear-by-Linear Association & .004 & 1 & .952 \\
N of Valid Cases & 356 & & \\
\hline
\end{tabular}

The above table reveals a undesirable relationship between the constructs, content analysis of all 4 newspapers newspaper are more or less highlighting the 'Clean and Green Pakistan' Campaign. Hence the hypothesis is partially rejected. 
The second hypothesis states that "Urdu print media/newspapers give more coverage to 'Clean and Green Campaign' than English Print Media/newspapers” has been tested by Pearson Chi-Square.

\section{Table 2}

\begin{tabular}{llll}
\hline & Value & df & Asymp. Sig. (2-sided) \\
\hline Pearson Chi-Square & $11.309^{\mathrm{a}}$ & 6 & .079 \\
Likelihood Ratio & 12.629 & 6 & .049 \\
Linear-by-Linear Association & 3.620 & 1 & .057 \\
N of Valid Cases & 30 & & \\
\hline
\end{tabular}

Chi -Square value in the table shows the significant results that Urdu print media/ newspaper has given more coverage to 'Clean and Green campaign' than English newspaper through news and advertisements. Hence the hypothesis is rejected.

The purpose of this study is intended to collect data from February 2019 to April 2019 from four leading newspapers in which two newspapers are English while other two are Urdu newspaper i-e: Nawai-Waqt, Jang, Dawn and The News in order to sense the part of print media in promoting Clean and Green Pakistan.

\section{Jang Newspaper}

In February there were two headlines and two advertisements published, which were very less in number to run a huge campaign like Clean and Green Pakistan. There was no positive news published in the month of February 2019, which was very harmful for the Clean and Green Campaign. There were two news published on 14 and 19 February 2019, both were negative. There was no balanced news issued in February 2019. There were two positive advertisements issued in February on $1^{\text {st }}$ and $13^{\text {th }}$ of 2019 . There were no negative and balanced advertisements in Jang newspaper in February 2019.

In March there were eight news and four Advertisements published in Daily Jang Urdu newspaper. There were two Positive news issued in March 2019. There were six news which were negative published on 12 - 17 and 19 of March 2019 in Daily Jang Urdu newspaper. There was no balanced news issued in March in Daily Jang Urdu Newspaper. Advertisements published on 11, 14, 18 and 20 March 2019 were positive, published in Daily Jang Urdu Newspaper. There were no negative and balanced advertisements published in Daily Jang Newspaper in March 2019.

In April 2019 there were only three news and two advertisements published in Daily Jang Urdu newspaper which were related to Clean and Green Pakistan. There was only single positive news published in Daily Jang Urdu newspaper on 02 April 2019. In the month of April there were two negative news published on 2nd April 2019. There was no balanced news issued in April 2019. There were two Positive Advertisements published in the month of April 2019.

\section{Nawa-i-Waqt Newspaper}

In the month of February 2019 there were three news issued in Nawa-i-Waqt related to Clean and Green Pakistan Campaign. There was only one news issued in Nawa-i-Waqt on $22^{\text {nd }}$ February, 2019. There was only one news issued in Nawa-i-Waqt on 19th February 2019. There was only single news issued in Nawa-i-Waqt on 10th February 2019 which was balanced. There was only one advertisement published on 9th February 2019 was positive. There were no negative and balanced advertisements issued in February. 
In March, it had been observed that there were eight such news and one advertisement published in Nawa-i-Waqt newspaper, which were related to Green Pakistan not related to Clean Pakistan. It had been observed that there were only two positive news were published on 14th and the 21st of March 2019. In the month of March there were four negative news issued in Nawa i Waqt on $14^{\text {th }}, 15^{\text {th }}, 17^{\text {th }}, 22^{\text {nd }}, 23^{\text {rd }}$ and $24^{\text {th }}$ March 2019. There were three balanced news issued in Nawa -i- Waqt on 16th and 17th March. There was only one positive Advertisement issued in (Nawa-i-Waqt, 2019).

In the month of April 2019 there were total three news issued in Nawa- i- Waqt related to Clean and Green Pakistan Campaign which were negative. There were three news issued in Nawa-i-Waqt on 1st, 17th and 28th April 2019, which were negative. It had been observed that there was no advertisement published in April 2019 related to Clean and Green Pakistan.

\section{Dawn Newspaper}

In the month of February 2019 there were no news and advertisements published in Dawn related to Clean and Green Pakistan Campaign.

In the month of March, there were two articles published on 12th and 16th of March and two advertisements published in DAWN on 7th and 21st of March 2019. News published on 12th March 2019 was positive. In the month of March there was no news published in the DAWN newspaper, which was negative. There was no balanced news published in the Dawn newspaper in the month of March. Advertisement published on 7th and 21st March 2019 were positive. There were no negative and balanced advertisements in the DAWN newspaper in March.

In April there were only three advertisements published in DAWN newspaper which were related to Clean and Green Pakistan. Advertisements published on 3rd, 12th and 22nd April 2019 were positive. There were no negative and balance advertisements in the DAWN newspaper in the month of April.

\section{The News}

In the month of February there was only one news published in The News English newspaper. In the month of February there was only one news published in The News. There were no negative and balanced news published in the month of February 2019 in The News English newspaper. In the month of March 2019 there were two news issued in The News. There were two positive news published in the Month of March 2019 on 8th and 14th March 2019 in The News. There were no advertisements issued in March. There were no news and advertisements published in newspaper about Clean and Green Pakistan.

\section{Conclusion}

Print media raised more concerns on this campaign in March rather than other months because the month of March is based on spring season. Selected print media did not only focus on the Clean Pakistan but also focused on the Green Pakistan. Both selected Urdu and English based newspapers did not appreciate the efforts of local Pakistani workers working at any place for this campaign. It was observed that negative news published in Urdu print media more rather than English print media. Pakistani print media published news most of the time for the image building of the politicians and less for the promotion of 'Clean and Green Pakistan Campaign'. English newspapers published news based on Clean and Green Campaign, it consists of minimum five to six columns. While news published in selected Urdu print media were hardly based on three to four columns, most of the time news based on only one column.

Advertisements published in selected Urdu and English print media most of the time were positive covered one fourth space of the newspaper page. It can be concluded that most of the news were negative 
in highlighting this issue. Such kinds of coverage leave a bad impression on the promotion of 'Clean and Green Pakistan' Campaign in the entire world especially in Asia. Pakistan is considered at the top in deforestation (Qamer et al., 2016). Pakistan is our country and home. Therefore, we must keep it clean, tidy and green, which will have great positive impact on our environment and health. In order to realize people about the importance of clean and green campaign it's necessary to highlight this campaign through newspapers by publishing news of people taking part in Clean and Green Campaign instead of politician. While, Pakistani media is also not playing its part in promoting the Clean and Green Campaign. Media sets agenda and penetrate its thoughts that are not beneficial for Pakistan's future. To conclude, it can be said that print media and chief editors must adopt favorable policies for the better image of the country and they must try to create goodwill of the country in front of other countries by promoting Clean and Green Campaign.

\section{Limitations of the study}

Limitations of the study are as following:

- $\quad$ Only the four newspapers i.e. Nawa-i-Waqt, Jang, Dawn and The News were analysed.

- $\quad$ The study is limited to three months from February to April 2019.

- $\quad$ News and advertisements are considered only to analyze the research study.

- This study is only based on the content analysis method. Other methodology can be adopted as well.

\section{References}

Agarwal, A., \& Narain, S. (1991). Global warming in an unequal world: A case of environmental colonialism (Vol. 17). New Delhi: Centre for Science and Environment.

Akram, R., Turan, V., Wahid, A., Ijaz, M., Shahid, M. A., Kaleem, S., \& Mubeen, M. (2018). Paddy land pollutants and their role in climate change. In Environmental Pollution of Paddy Soils 113-124. Springer, Cham.

Ali, J., Benjaminsen, T. A., Hammad, A. A., \& Dick, Ø. B. (2005). The road to deforestation: An assessment of forest loss and its causes in Basho Valley, Northern Pakistan. Global Environmental Change, 15(4), 370-380.

Ferraz, G., Nichols, J. D., Hines, J. E., Stouffer, P. C., Bierregaard, R. O., \& Lovejoy, T. E. (2007). A large-scale deforestation experiment: effects of patch area and isolation on Amazon birds. science, 315(5809), 238-241.

Green, T., \& Peloza, J. (2014). Finding the right shade of green: The effect of advertising appeal type on environmentally friendly consumption. Journal of Advertising, 43(2), 128-141.

Hanasaki, N., Inuzuka, T., Kanae, S., \& Oki, T. (2010). An estimation of global virtual water flow and sources of water withdrawal for major crops and livestock products using a global hydrological model. Journal of Hydrology, 384(3-4), 232-244.

Kozma, R. B. (1991). Learning with media. Review of educational research, 61(2), 179-211.

Leggett, J. (1990). Global warming: the Greenpeace report. Oxford University Press.

Maibach, E. W., Nisbet, M., Baldwin, P., Akerlof, K., \& Diao, G. (2010). Reframing climate change as a public health issue: an exploratory study of public reactions. BMC public health, 10(1), 299. 
Mathews, B. W., \& Thurkins, C. J. (2006). Agronomic responses in the short-term to some management options for sugarcane top residues. J. Hawaiian Pac. Agric, 13, 23-34.

Mohamed, H. M. (2015). Green, environment-friendly, analytical tools give insights in pharmaceuticals and cosmetics analysis. TrAC Trends in Analytical Chemistry, 66, 176- 192.

Parrish, D. D., \& Zhu, T. (2009). Clean air for megacities. Science, 326(5953), 674-675.

Peters, B. G., \& Hogwood, B. W. (1985). In search of the issue-attention cycle. The journal of politics, $47(1), 238-253$.

Qamer, F. M., Abbas, S., Saleem, R., Shehzad, K., Ali, H., \& Gilani, H. (2012). Forest cover change assessment in conflict-affected areas of northwest Pakistan: The case of Swat and Shangla districts. Journal of Mountain Science, 9(3), 297-306.

Qamer, F. M., Shehzad, K., Abbas, S., Murthy, M. S. R., Xi, C., Gilani, H., \& Bajracharya, B. (2016). Mapping deforestation and forest degradation patterns in western Himalaya, Pakistan. Remote Sensing, 8(5), 385.

Rahim, M. H. A., Zukni, R. Z. J. A., Ahmad, F., \& Lyndon, N. (2012). Green advertising and environmentally responsible consumer behavior: The level of awareness and perception of Malaysian youth. Asian Social Science, 8(5), 46.

Raza, S. H., Awan, S. M., \& Iftikhar, M. (2018). Effect of the Cultural Gender Role Orientation on Advertising Intrusiveness and the Moderating effect of Self-referencing: An Experimental Study. Journal of the Research Society of Pakistan, 55(1).

Sarwar, N., Imran, M., Shaheen, M. R., Ishaque, W., Kamran, M. A., Matloob, A., \& Hussain, $\quad$ S. (2017). Phytoremediation strategies for soils contaminated with heavy metals: modifications and future perspectives. Chemosphere, 171, 710-721.

Shehzad, K., Qamer, F. M., Murthy, M. S. R., Abbas, S., \& Bhatta, L. D. (2014). Deforestation trends and spatial modelling of its drivers in the dry temperate forests of northern Pakistan-A case study of Chitral. Journal of Mountain Science, 11(5), 1192-1207.

Stamm, K. R., Clark, F., \& Eblacas, P. R. (2000). Mass communication and public understanding of environmental problems: the case of global warming. Public understanding of science, $9(3)$, 219-238.

Vitousek, P. M. (1983). The effects of deforestation on air, soil, and water. The major biogeochemical cycles and their interactions, 223-245.

Witte, K., \& Allen, M. (2000). A meta-analysis of fear appeals: Implications for effective public health campaigns. Health education \& behavior, 27(5), 591-615.

Xue, F., \& Zhou, P. (2012). Greener on the Other Side? A Comparative Content Analysis of Environmental Claims in Magazine Advertisements in China and the United States. Journal of Magazine \& New Media Research, 13(2). 